\title{
Self-efficacy and Reading Test Result in Senior High School: Does it Correlate?
}

\author{
Zubaedah Wiji Lestari $^{1{ }^{1 *}}$, Mursyid Saleh${ }^{2}$, Januarius Mujiyanto ${ }^{2}$, Suhendra Yusuf ${ }^{1}$ \\ ${ }^{1}$ Department of English Language, Universitas Islam Nusantara, Bandung, West Java, Indonesia \\ ${ }^{2}$ Department of English Language, Universitas Negeri Semarang, Central Java, Indonesia
}

Received May 10, 2020 ; Revised June 20, 2020; Accepted July 20, 2020

\section{Cite This Paper in the following Citation Styles}

(a): [1] Zubaedah Wiji Lestari, Mursyid Saleh, Januarius Mujiyanto, Suhendra Yusuf , "Self-efficacy and Reading Test Result in Senior High School: Does it Correlate?," Universal Journal of Educational Research, Vol. 8, No. 9, pp. 3907 3915, 2020. DOI: 10.13189/ujer.2020.080915.

(b): Zubaedah Wiji Lestari, Mursyid Saleh, Januarius Mujiyanto, Suhendra Yusuf (2020). Self-efficacy and Reading Test Result in Senior High School: Does it Correlate?. Universal Journal of Educational Research, 8(9), 3907 - 3915. DOI: 10.13189/ujer.2020.080915.

Copyright $\odot 2020$ by authors, all rights reserved. Authors agree that this article remains permanently open access under the terms of the Creative Commons Attribution License 4.0 International License

\begin{abstract}
This study aims to examine the reading scores of a second-grade class in a public school and their relationship to student self-efficacy. Given the importance of students' self-efficacy in reading test results, this study uses a mixed-methods approach. Samples were taken using a purposive sampling technique with one class consisting of thirty-four students who participated in this study. In this study, data were collected from a self-efficacy scale and reading test. To see the relationship between self-efficacy and student reading tests, the authors conducted a Pearson simple correlation test. From the result of the Pearson simple correlation formula, the findings show that there is very close parallelism between students' self-efficacy and reading tests. This current study indicates that higher students' self-efficacy will actively enhance the quality of teaching-learning activity. One of which is by giving encouragement and constructive feedback to the students continuously. However, it also has some limitations in terms of length of study and data collection. First, after knowing that self-efficacy has a close correlation with student reading results, then further research in implementing ways to improve student self-efficacy will be beneficial to improve student self-efficacy. Second, the study results found that there are students who are at a low level of self-efficacy. Thus, further research can be conducted by collecting other research data such as questionnaires or interviews to explore the factors that cause their low self-efficacy and then look for efforts to improve it.
\end{abstract}

Keywords Self-efficacy, Reading Achievement, English as a Foreign Language

\section{Introduction}

Cognitive factors are not the only determinant of successful learning [1], [2]. Many factors play a role in learning activities, which are interrelated and support one another. Furthermore, few studies found in the literature were focusing on what and how factors that give some influence are related to organizational learning and knowledge sharing taken as a synergistic process [3], [4]. Various other studies prove that in addition to cognitive components, social and psychological factors also have a forceful influence and should be taken into account in the success of education [5]-[8]. Even in recent years, there has been a new trend that other factors besides non-cognitive can become one determining factor in education [2], [9]-[14]. The non-cognitive factors in classroom activity may in the form of students' encouragement in learning, students' state of feeling, mental conviction, and contextual features [15]-[19]. Furthermore, forward a taxonomy suggests that non-cognitive factors, four categories support the quality of learning [20]. Learners' attitudes, self-confidence, social quality, and the ability to manage emotions are elements that can support learning success. 
To have self-efficacy means someone has confidence in their qualifications [21], [22]. When someone has strong confidence that they can captivate alteration in their lives, they will have more passion for achieving their goals [23], [24]. Self-efficacy influence and can be a determinant of the success of the learning process because it connects with someone's belief that influence their performance on those tasks. Self-efficacy that someone owns can be obtained, modified, enhanced, or even derived through four primary sources: active mastery experience, vicarious experience, verbal persuasion, and someone physiological states [23][25]. Referring to this theory, in terms of reading in English lessons, students need to have high self-efficacy in reading. By possessing high self-efficacy in reading, students can read and understand texts well, work on tasks related to reading, and have the confidence to complete challenging reading assignments.

Research on self-efficacy in the world of education was conducted by researchers from various disciplines [26][30]. One of them is the research examining the relationship between self-efficacy and students' mathematical connection abilities [29]. Students who were previously studied received two different treatments. One group got treatment using the Brain-Based Learning approach that applies EQ and SQ, while the other group of students got learning conventionally.

In language learning, there are several skills that students must master, including reading, speaking, and listening skills [31]-[34]. Along with changing times, knowledge develops rapidly [35], [36]. The role of self-concept and learning motivation also plays a significant role, especially in the reading sphere. Some experts have proven the importance of psychological aspects such as motivation, which shows a tendency for high motivation, task-oriented, and student social dependence [37]. Further study results indicate the existence of cognitive-linguistic needs in reading and mathematics skills. Research carried out continuously from the start of students in kindergarten (ages 5-6 years), up to grade 1 elementary school (6-7 years old), predicting students' ability in the decoding process, understanding of reading texts, and achieving arithmetic in second grade. Besides, the results of this study indicate that non-cognitive aspects will support students' success at the next educational level.

As stated in the previous paragraph, the level of self-efficacy affects one's confidence in completing the task. In the reading class, previous research aimed at studying the relationship between self-efficacy and participants' reading achievement carefully [38]. For this reason, this study conducted to answer research questions from this study that investigate the correlation between student self-efficacy and student reading scores?

\section{Methods}

This particular research implemented quantitative correlational, which investigates variations in a variable related to variations in one or more other variables based on the correlation coefficient [39], [40]. The researcher wants to find out the correlation between the level of self-efficacy and students' reading results. The calculation is done using Pearson's simple correlation test. Furthermore, qualitative explanations are presented to narrate the findings from quantitative calculation results. The analysis was delivered out aimed at broadening and explaining the research result [41], [42].

The population in this study was $11^{\text {th }}$ grade students of Senior High School at 11 Bandung, consisting of 12 classes totaling 420 people. In this study, the participant was one class of second grade of the senior high school consists of 34 students with a composition of 6 male students and 28 female students. In this case, the researchers do not choose the sample conveniently but based on prior information that this class meets the research requirement [43]. The selection of class for research made by a purposive sampling technique, that is, the selection based on specific criteria according to the research objectives [44]-[46]. In this study, the class selection was made because the class used is the language class.

Data collection performed using a self-efficacy scale and reading test. The self-efficacy scale was given to students at the beginning of the study to determine the students' self-efficacy level. There is a self-efficacy measurement tool widely known and designed to assess a person's confidence in overcoming a problem known as the General self-efficacy scale. The general self-efficacy scale that has been developed so far is intended for individuals aged 12 years and over [47]. Nevertheless, in this study, researchers with the help of psychologists with the psychometric specialization develop a self-efficacy scale specific to the field of reading. A reading test was given to students to determine the students' ability to read a text and answer a high order thinking skill question. The test used in this study was a standardized test used in the 2019 English National Examination. In the National Examination, the test consists of the listening section and the reading section; however, in this study, the test given was only the reading section.

To see the relationship between self-efficacy and student reading tests, researchers used regression analysis. The hypothesis test proposed was that there is a relationship between self-efficacy and student reading results. The four steps that the authors take were are: firstly, giving the self-efficacy scale to students. Secondly, analyze the results of the question given to find out students' self-efficacy level, and classify students at low, medium, and high self-efficacy levels. Thirdly, give students a reading test. Analyze the results of the reading test and grouping students into high, medium, and low groups. Fourthly, after obtaining two data, namely students' self-efficacy scale, and students' reading scores, researchers do the calculations using regression. 
Regression analysis is a statistical test used to measure the strength of relationships of 2 or more variables and also to be able to find out the relationship between 2 or more variables with quantitative results [48]-[50]. The potential of these variables states whether the relationship is close, weak, or not close while the relationship is whether the correlation is positive linear or negative linear [48], [49].

\section{Results and Discussion}

This section describes the findings and discussion obtained from the instruments used in the study. To facilitate understanding, this findings section is divided into four parts, namely: research administration, students self-efficacy level category, a student reading results based on reading tests, and the correlation between students' self-efficacy and reading tests.

\subsection{Research Administration}

The study was conducted in one public senior high school at 11 Bandung, West Java. In this study, researchers with the help of local teachers conduct the research together. In the classroom, the study begins by informing the purpose of the research (informed consent). Next, the researchers analyze students' identities, even if not mentioned in the research report. Stages are carried out following the principle of research ethics in terms of an anonymous participant.

Unknown beforehand, it turns out the school where the study conducted held an inclusion program. The statement means students with special needs go to school together with ordinary students. In the classroom where the study was conducted, there were two visual impairment students. Blind students have visual impairments, both those with little or no vision [51]-[54]. Since 1900, an inclusion program has been carried out in the United States by including students who cannot see in-school programs for students who do not have special needs [55], [56]. The inclusion approach believes that the student with special needs must mingle with ordinary students who are in general education and can access the general education curriculum [57]. Nevertheless, these students' conditions did not hinder the research process, even though they received different treatment. For two students with visual impairment, to fill in the scale of self-efficacy, the researcher reads out the statements and helps them to fill in the answers following their psychological state through the Google form. For the reading test, because the question consists of several texts with five answer choices that are not possible to do in school, the researchers provided the soft file through the WhatsApp, and students did it at home with the help of their family. By considering the process, the two students with visual impairment can still be used as research participants.

\subsection{Self-efficacy Scale}

In order to be able to measure students' self-efficacy appropriately, the researcher designed a scale that measured students' reading self-efficacy. The researcher develops a specific measurement tool because the reading tasks that students face vary widely. Moreover, the students are also exposed by many kinds of texts in their classroom and daily life. Therefore, the scale of self-efficacy in reading should be able to reflect accurately measuring the level of student confidence in reading assignments.

In the self-efficacy blueprint, the statements are divided into three sections that fulfill three dimensions of self-efficacy: magnitude, strength, and generality [58]-[60]. The first is the aspect of magnitude regarding students' beliefs in terms of their ability to solve various levels of difficulty in reading assignments. Indicators of this aspect are students' confidence in choosing strategies and confidence they can answer reading tasks with varying degrees of difficulties [58], [61]. Second is the strength aspect, which includes an individual's confidence in completing reading assignments. Indicators of this aspect are belief in the efforts made in completing the reading task and the resilience and tenacity of students in reading and answering questions [59], [62]. The third is the generality aspect, which is the area of behavior, including the beliefs of students completing various variations of reading tasks. Indicators of this aspect are students' confidence that can solve various reading problems and confidence and have consistency in various situations [60].

Each of those sections consists of 20 statements in the form of favorable and unfavorable statements. Favorable is a statement that supports while unfavorable is a statement that does not support. Table 1 shows the blueprint of the self-efficacy scale in this study. Responses on the self-efficacy scale are given in the form of four choices based on a Likert scale. The scale starts from the one that best suits the student's condition to the one that is least suited to the student's condition.

Table 1. Blueprint of Self Efficacy Scale

\begin{tabular}{|c|c|c|}
\hline \multirow{2}{*}{$\begin{array}{c}\text { Dimension of } \\
\text { self-efficacy }\end{array}$} & \multicolumn{2}{|c|}{ Item Number } \\
\cline { 2 - 3 } & Favorable & Unfavorable \\
\hline \multirow{2}{*}{ Magnitude } & $1,2,3,4,5,11,12$, & $6,7,8,9,10,16,17$, \\
& $13,14,15$ & $18,19,20$ \\
\hline \multirow{2}{*}{ Strength } & $21,22,23,24,25$, & $26,27,28,29,30$, \\
& $31,32,33,34,35$ & $36,37,38,39,40$ \\
\hline \multirow{2}{*}{ Generality } & $41,42,43,44,45$, & $46,47,48,49,50$, \\
& $51,52,53,54,55$ & $56,57,58,59,60$ \\
\hline
\end{tabular}

The self-efficacy scale is designed following the blueprint for students can understand and respond efficiently. The self-efficacy scale was given to students online through Google form. Giving scale through Google Form is done with various considerations, including being more environmentally friendly because it is paperless, charging time is faster, and the data processing is carried 
out faster and more efficiently. In this study, the self-efficacy scale and reading test results were placed on a continuum in the low, medium, and high category ranges. If the scale can accurately measure students' confidence in reading assignments, then the results obtained from this use can be used to predict students' self-efficacy in carrying out various tasks in the future [23], [25].

As in the previous section that Self-efficacy is divided into three categories, namely low, medium, and high. The categorization refers to table 2. Categorization is done to place individuals into separate groups in stages according to a continuum based on the attributes measured in this case, students' ability to carry out reading assignments.

Table 2. Self -efficacy Level

\begin{tabular}{|c|c|}
\hline Level & Interval \\
\hline High & $160<$ Self-Efficacy Score $\leq 240$ \\
\hline Medium & $120<$ Self-Efficacy Score $\leq 160$ \\
\hline Low & $60 \leq$ Self-Efficacy Score $\leq 120$ \\
\hline
\end{tabular}

After getting students' responses, and researchers have grouped them into three categories. It was revealed that three students were at a low level of self-efficacy, 16 students were at a moderate level of self-efficacy, and 15 students were at a high level of self-efficacy (see figure 1). Figure 1 shows that a small proportion of students (8\%) are at a low level of self-efficacy, $48 \%$ are at a moderate level of self-efficacy, and $44 \%$ are at a high level of self-efficacy.

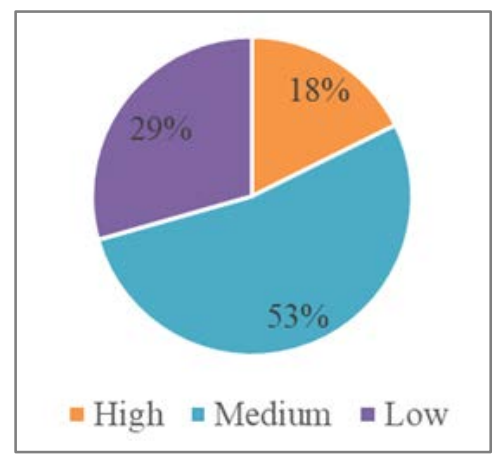

Figure 1. The percentage of Students Self-Efficacy Level

\subsection{Student Reading Scores}

To determine students' reading skills, the researchers conducted a reading test. The researchers use a standardized test used in the 2019 English National Examination with several assumptions, namely: 1) the test contains $20 \%$ of the questions included in the high order thinking category, and it is appropriate to expose this test to grade 11 so that they start to get used to dealing with high order thinking problems, 2) the test has been through the design and development carried out by a cross-sectoral expert team. It has been tested and tried out for validity and reliability so that it is considered suitable to use it in this research. However, to strengthen the test's validity and reliability, the researchers tried out to three classes of 11-grade students. The tried out was conducted to test the reliability and readability. Furthermore, it was intended to ensure that the items in the test have a level of compatibility with the sample. An item test analysis is carried out to determine the difficulty of the test (item difficulty index or facility index) and obtain information about whether the questions given can distinguish between students who get good grades or get bad grades (discrimination index). The tryout test results obtained that as many as 4 questions are in the easy category because the proportion of students who answer to the number of students is more than $0.75 ; 4$ questions in the difficult category. After all, the proportion of students who responded to the number of students was less than 0.25 , and the rest were in the moderate category. Besides, all the questions used can distinguish between students who get good grades or get bad grades.

The test was given in the form of multiple-choice with four possible answers. The form of the questions consists of low order thinking and high order thinking skills questions. The multiple-choice form makes it easier for the teacher to provide assessments and relate them to self-efficacy. Another reason is to meet the practicality criteria, namely conducted within appropriate time constraints, and the evaluation procedure is specific [63][65]. The test consists of 35 questions with 20 percent include the high order thinking category. From the reading test results, the researcher divides the results of student scores into three parts, namely those who get low, medium, and high scores. Because the form of the test is an objective test, the correct answer is scored one, and the incorrect answer is scored zero. Those whose in the low-value category is if the actual value is 0 to 11 , those whose within the medium value category is if the actual value is 12 to 23 , and those whose within the high-value category is when the real value is 24 to 35 . The reading test reveals that the highest score is 28 , and the lowest score is 3 . Figure 2 illustrates the result of students reading scores. After being analyzed, of 35 students, six students were included in the low category, 18 students within the moderate category, and ten students were within the high category.

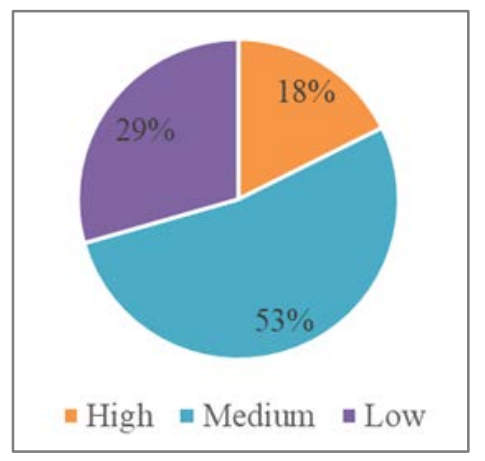

Figure 2. Percentage of Students Reading Score 


\subsection{The Relationship between Self-efficacy with Reading Test}

To see the relationship between self-efficacy and the reading test, the researchers used Pearson's simple correlation test. The hypothesis proposed is H0: There is no relationship between self-efficacy, and H1: Test reading: There is a relationship between self-efficacy and reading test. Table 3 is the results of the correlation test.

Table 3. Correlation Test Results

\begin{tabular}{|c|c|c|c|}
\hline \multicolumn{2}{|c|}{} & Reading Test & Self-Efficacy \\
\hline \multirow{2}{*}{$\begin{array}{c}\text { Pearson } \\
\text { Correlation }\end{array}$} & Reading Test & 1.000 & .693 \\
\cline { 2 - 4 } & Self-Efficacy & .693 & 1.000 \\
\hline \multirow{2}{*}{ Sig. (1-tailed) } & Reading Test &. & .000 \\
\cline { 2 - 4 } & Self-Efficacy & .000 &. \\
\hline
\end{tabular}

Table 3 shows that Pearson's correlation coefficient is 0.720 , which shows the direction of a positive relationship. Then, that value of sig. (2-tailed) of $0.000<0.05$ indicates that there are not enough conditions to accept $\mathrm{HO}$, so $\mathrm{H} 1$ is accepted. The result implies that there is a significant relationship between self-efficacy and reading tests. Because the direction of the relationship is positive, it can be said that the higher the student's self-efficacy, the higher the reading test score. In simple terms, it means that students who have high self-efficacy are also included in students who score high on the reading test. Students who have a moderate level of self-efficacy are within students who are currently on the reading test. Students who have low levels of self-efficacy are within students who score low on the reading test.

This result is also supported by the results of the regression calculation. Where the regression calculations obtained an R coefficient of 0.693 , with R square of 0.480 (see Table 4). This shows that the contribution of self-efficacy to the reading test was $48 \%$, while the other $52 \%$ was influenced by other factors. Other factors such as Intelligence Quotient, Emotional Quotient, and student anxiety [66], [67].

The positive correlation between self-efficacy and reading tests can interpret that the level of self-efficacy affects student achievement. Besides, the results of this study are supported by the estimation of the regression line equation that is $\mathrm{Y}=0.171 \mathrm{X} 1-11.901$, where $\mathrm{X} 1$ is self-efficacy (see table 5 ). These findings reinforce previous studies, which stated that self-efficacy has a significant influence on how a person tries to work, carry out the assigned task, complete the assigned task, and solve the problem to achieve the goals you want to expect [68]. Furthermore, other research states that trust in one's abilities is needed [69], [70]. By having confidence, students can regulate their behavior in taking action, optimize their efforts, and do not want to give up to achieve their goals and ideals.

Even though only a scatter of students at the level of small self-efficacy does not mean the teacher can just ignore it. It is better if efforts are made to improve students' self-efficacy to be at a higher level. By helping students develop self-regulation strategies in learning, students' confidence in completing learning tasks also increases [23]-[25]. As stated by Bandura, a self-organizing strategy is essential for the achievement of success in learning. Students expected to succeed and have the ability and knowledge of the subjects taught in the class [71].

Students are good at knowing things that can make learning successful such as time management, practical learning, a supportive learning environment, and support from students that they are confident and confident that they can succeed. The teacher also has a role in motivating students to develop their potential. The teacher must inspire students' self-confidence that each student has their unique potential and has specific intelligence according to the principle of multiple intelligences [72], [73]. For this reason, the teacher must be able to help students to develop their potential in making the challenges faced by students as opportunities for them to progress and help solve learning problems that may be faced by students.

Table 4. Model Summary of regression Analysis

\begin{tabular}{|l|c|c|c|c|c|c|c|c|c|}
\hline \multirow{2}{*}{ Model } & \multirow{2}{*}{$\mathrm{R}$} & R Square & $\begin{array}{c}\text { Adjusted R } \\
\text { Square }\end{array}$ & $\begin{array}{c}\text { Std. An error of the } \\
\text { Estimate }\end{array}$ & \multicolumn{5}{|c|}{ Change Statistics } \\
\cline { 6 - 10 } & & R Square Change & F Change & df1 & df2 & Sig. F Change \\
\hline 1 & $.693 a$ & .480 & .463 & 5.032 & .480 & 29.491 & 1 & 32 & .000 \\
\hline
\end{tabular}

Table 5. Calculation of estimated regression equations

\begin{tabular}{|c|c|c|c|c|c|c|}
\hline & \multirow{2}{*}{ Model } & \multicolumn{2}{|c|}{ Unstandardized Coefficients } & Standardized Coefficients & \multirow{2}{*}{$\mathrm{t}$} & \multirow{2}{*}{ Sig. } \\
\hline & & B & Std. Error & Beta & & \\
\hline \multirow{2}{*}{1} & (Constant) & -11.901 & 5.060 & & -2.352 & .025 \\
\hline & Self_Efficacy & .171 & .031 & .693 & 5.431 & .000 \\
\hline
\end{tabular}


In addition to continuing to motivate so that students' self-efficacy can improve, the environment around the teacher and other friends is also right to provide reinforcement and opportunities for students to work independently. Creativity is the essence of learning and development. This creativity can increase when students have authority over the work process. Students can work independently with confidence to complete assignments if students are empowered by giving them more authority over the work processes they do [74].

Furthermore, for students to have the understanding to focus on learning progress, the teacher must direct students to participate in achieving the strategic goals of the institution [24], [25]. In the process of learning that takes a long time, the institution's strategic objectives are proximal goals [23].

One way to help the students is to provide feedback on the work they have done. When getting feedback from the teacher, students will feel cared for, their work is valued, and their motivation for learning will increase. Feedback given to students can be recognized as a crucial strategy in learning and teaching [75]. Previous research has shown that feedback given by teachers in learning activities contributes positively to various things in students [76]. Feedback given by the teacher contributes to student self-efficacy, self-regulation ability in learning, participation in external goals, and especially the feeling of pleasure when learning in this regard in EFL teaching. Not only do teachers provide feedback, but even student feedback on learning given by teachers also provides valuable information for the development of learning. Students' feedback to teachers is useful in the next learning process [77]. Teachers with an open mind will receive students' feedback as meaningful input to improve the quality of learning.

Equitable feedback practice could further reduce students' maladaptive assessment agencies. With the feedback given by the student, he will feel actively involved in learning, and this will increase his self-efficacy because he feels he is a meaningful part of the class. Moreover, students' feedback is worth an essential source of information for the teacher to develop. It could maximize to analyze their teaching techniques to increase the quality of teaching. As we all know, the educational process optimizes the interaction between teachers and students. To maximize interaction and achieve learning goals, teachers must be able to analyze their teaching techniques, conduct need analysis, and then practice effective teaching techniques and meet the needs of students so that learning can take place optimally [78]. The achievement could be predicted by cognitive and background factors and by conscientiousness, self-efficacy, and test anxiety. Moreover, the predictive power of variables varies across study programs, which suggests that research findings of the forecasting of academic achievement might benefit from taking into account the specific program context [68].

\section{Conclusions}

Research conducted using quantitative correlational at Senior High School at 11 Bandung shows a close relationship between self-efficacy and student reading results. From the results obtained, there are several implications for learning. First, non-cognitive factors have the same important role as cognitive factors in the success of learning. Second, it is evident that the correlation between self-efficacy and reading scores is directly proportional, for it is essential to improve students' self-efficacy so that they have confidence in learning English, which will impact good learning outcomes. Third, one way to improve students' self-efficacy is to provide constructive feedback continuously. Fourth, with the increase in self-efficacy, students will have the ability to apply self-regulating strategies.

This research reveals many implications that are very beneficial for the development of education. However, it also has some limitations in terms of the length of study and data collection. After finding out that self-efficacy has a close correlation with student reading results, follow-up research in implementing ways to improve student self-efficacy will be beneficial for increasing student self-efficacy. Second, the study results found that there are students who are at a low level of self-efficacy. Thus, further research can be carried out with other research data collection such as questionnaires or interviews to explore the factors that cause their low self-efficacy and then look for efforts to improve it.

Despite these weaknesses, the present study opens up further conversations about how psychology pedagogical interventions in enhancing students' self-efficacy will subsequently affect the increased interest in learning and learning outcomes. Furthermore, hopefully, the increase in students' self-efficacy can make students self-regulating.

\section{REFERENCES}

[1] J. Park and L. Lee, “Analysing cognitive or non-cognitive factors involved in the process of physics problem-solving in an everyday context," Int. J. Sci. Educ., 2004, doi: 10.1080/0950069042000230767.

[2] A. Sommerfeld, "Recasting Non-Cognitive Factors in College Readiness as What They Truly Are: Non-Academic Factors,” J. Coll. Admiss., 2011.

[3] I. V. Herghiligiu, A. Pohonțu, M. Pislaru, and A. Vilcu, "Influencing Factors and Outcomes of the Learning by Sharing Process," Procedia - Soc. Behav. Sci., 2018, doi: 10.1016/j.sbspro.2018.03.008. 
[4] Wawan, E. F. Ningsih, S. A. Widodo, Leonard, R. M. Sary, and E. Retnowati, "The Cognitive Load of Learners in the Learning Process of the Rotating Object Volume," in Journal of Physics: Conference Series, 2019, doi: 10.1088/1742-6596/1315/1/012046.

[5] W. H. Sewell and R. M. Hauser, "The Wisconsin Longitudinal Study of Social and Psychological Factors in Aspirations and Achievements,” Res. Sociol. Educ. Social., 1980.

[6] B. K. Eckland, W. H. Sewell, and R. M. Hauser, "Education, Occupation, and Earnings: Achievement in the Early Career.," Contemp. Sociol., 1976, doi: 10.2307/2064158.

[7] C. H. Karels, S. M. A. Bierma-Zeinstra, A. Burdorf, A. P. Verhagen, A. P. Nauta, and B. W. Koes, "Social and psychological factors influenced the course of arm, neck and shoulder complaints,” J. Clin. Epidemiol., 2007, doi: 10.1016/j.jclinepi.2006.11.012.

[8] D. S. Yeager and G. M. Walton, "Social-psychological interventions in education: They're not magic," Review of Educational Research. 2011, doi: 10.3102/0034654311405999.

[9] E. García, "The Need to Address Non-Cognitive Skills in the Education Policy Agenda1,” in Non-cognitive Skills and Factors in Educational Attainment, 2016.

[10] B. A. Jacob, "Where the boys aren't: Non-cognitive skills, returns to school and the gender gap in higher education," Econ. Educ. Rev., 2002, doi: 10.1016/S0272-7757(01)00051-6.

[11] M. Komarraju, A. Ramsey, and V. Rinella, "Cognitive and non-cognitive predictors of college readiness and performance: Role of academic discipline,” Learn. Individ. Differ., 2013, doi: 10.1016/j.lindif.2012.12.007.

[12] J. R. Sparkman, L.A., Maulding, W.S., Roberts, "Non-Cognitive Predictors Of Student Success In College," Coll. Stud. J., 2012.

[13] M. Ardiyaningrum, L. Badriah, Trisniawati, Suhartini, and S. A. Widodo, "Differential item function of gender in the mathematics elementary school tryout test," in Journal of Physics: Conference Series, 2019, doi: 10.1088/1742-6596/ 1315/1/012036

[14] S. A. Widodo, J. A. Dahlan, and Turmudi, "Can Sociomathematical Norms Be Developed With Learning Media?,” J. Phys. Conf. Ser., vol. 1315, no. 1, 2019, doi: 10.1088/1742-6596/1315/1/012005

[15] C. A. Farrington et al., "Teaching adolescents to become learners: The role of noncognitive factors in shaping school performance: A critical literature review," Chicago Univ. Chicago Consort. Chicago Sch. Res., 2012.

[16] C. a Farrington et al., "The role of noncognitive factors in shaping school performance: A critical literature review," Teach. Adolesc. To Become Learn., 2012.

[17] S. A. Widodo and A. S. Purnami, "Mengembangkan Norma Sosiomatematik dengan Team Accelerated Instruction," Numer. J. Mat. dan Pendidik. Mat., vol. 2, no. 1, pp. 29-48, 2018.

[18] S. A. Widodo, J. A. Dahlan, E. Harini, and F. Sulistyowati, "Confirmatory factor analysis sosiomathematics norm among junior high school student,” vol. 9, no. 2, pp. 448455, 2020, doi: 10.11591/ijere.v9i2.20445.

[19] Trisniawati, M. Titi Muanifah, N. Rhosyida, S. Adi Widodo, and M. Ardiyaningrum, "Exploration towards attitude of students in elementary school teacher education in mathematics learning," in Journal of Physics: Conference Series, 2019, doi: 10.1088/1742-6596/1315/1/012033.

[20] A. A. Lipnevich and R. D. Roberts, "Noncognitive skills in education: Emerging research and applications in a variety of international contexts,” Learn. Individ. Differ., 2012, doi: 10.1016/j.lindif.2011.11.016.

[21] J. Lane, A. M. Lane, and A. Kyprianou, "Self-efficacy, self-esteem and their impact on academic performance," Soc. Behav. Pers., 2004, doi: 10.2224/sbp.2004.32.3.247.

[22] G. Mettasari, "Self-Esteem, Achievement Motivation, SelfEfficacy and Students ' Anxiety in Speaking," J. Pendidik. dan Pengajaran, vol. 46, no. 2, pp. 163-173, 2013.

[23] A. Bandura, W. H. Freeman, and R. Lightsey, "Self-Efficacy: The Exercise of Control,” J. Cogn. Psychother., 1999, doi: 10.1891/0889-8391.13.2.158.

[24] A. Bandura, "Self-efficacy: Toward a unifying theory of behavioral change,” Psychol. Rev., 1977, doi: 10.1037/0033-295X.84.2.191.

[25] A. Bandura, "Guide for constructing self-efficacy scales," Self-efficacy beliefs Adolesc., 2006, doi: 10.1017/CBO9781107415324.004.

[26] F. O. Walumbwa, D. M. Mayer, P. Wang, H. Wang, K. Workman, and A. L. Christensen, "Linking ethical leadership to employee performance: The roles of leader-member exchange, self-efficacy, and organizational identification,” Organ. Behav. Hum. Decis. Process., 2011, doi: 10.1016/j.obhdp.2010.11.002.

[27] P. Runhaar, K. Sanders, and H. Yang, "Stimulating teachers' reflection and feedback asking: An interplay of self-efficacy, learning goal orientation, and transformational leadership," Teach. Teach. Educ., 2010, doi: 10.1016/j.tate.2010.02.011.

[28] L. Baron and L. Morin, "The impact of executive coaching on self-efficacy related to management soft-skills," Leadersh. Organ. Dev. J., 2010, doi: 10.1108/01437731011 010362.

[29] L. L. Hakim, E. Cahya, E. Nurlaelah, and Z. W. Lestari, "The Application Eq And Sq In Learning Mathematics With Brain-Based Learning Approach To Improve Students' Mathematical Connection And Self-Efficacy In Senior High School,” PEOPLE Int. J. Soc. Sci., vol. 1, no. 1, pp. 542-557, 2015.

[30] E. M. Skaalvik, R. A. Federici, and R. M. Klassen, "Mathematics achievement and self-efficacy: Relations with motivation for mathematics,” Int. J. Educ. Res., vol. 72, pp. 129-136, 2015, doi: 10.1016/j.ijer.2015.06.008.

[31] C. T. Mart, “Developing Speaking Skills through Reading,' Int. J. English Linguist., 2012, doi: 10.5539/ijel.v2n6p91.

[32] H. Küçükoğlu, "Improving Reading Skills Through Effective Reading Strategies," Procedia - Soc. Behav. Sci., 2013, doi: 10.1016/j.sbspro.2013.01.113.

[33] P. M.-M. Sze, “Developing Students' Listening and 
Speaking Skills through ELT Podcasts.,” Educ. J., 2006.

[34] M. G. C. Plana, M. I. G. Escofet, I. T. Figueras, A. Gimeno, C. Appel, and J. Hopkins, "Improving Learners' Reading Skills Through Instant Short Messages: A Sample Study Using WhatsApp," in WorldCALL: Sustainability and Computer-Assisted Language Learning, 2013.

[35] N. Förster and E. Souvignier, "Learning progress assessment and goal setting: Effects on reading achievement, reading motivation and reading self-concept,” Learn. Instr., 2014, doi: 10.1016/j.learninstruc.2014.02.002.

[36] Y. Park, "How motivational constructs interact to predict elementary students' reading performance: Examples from attitudes and self-concept in reading," Learn. Individ. Differ., 2011, doi: 10.1016/j.lindif.2011.02.009.

[37] J. Lepola, P. Niemi, M. Kuikka, and M. M. Hannula, "Cognitive-linguistic skills and motivation as longitudinal predictors of reading and arithmetic achievement: A follow-up study from kindergarten to grade 2,” Int. J. Educ. Res., 2005, doi: 10.1016/j.ijer.2006.06.005.

[38] P. R. Richardson, "Reading self-efficacy in early adolescence: Which measure works best?,” ProQuest Diss. Theses, 2013.

[39] A. J. Onwuegbuzie and R. B. Johnson, "Mixed methods research: A research paradigm whose time has come," Educ. Res., vol. 33, no. 7, pp. 14-26, 2004, doi: 10.3102/0013189X033007014.

[40] A. E. Kelly and R. A. Lesh, Handbook of Research Design in Mathematics and Science Education. New Jersey: Lawrence Erlbaum Ass. Inc, 2010.

[41] J. W. Creswell, Educational Research: Planning, Conducting and Evaluating Quantitative and Qualitative Research. London: Pearson, 2012.

[42] J. W. Creswell, Research Design Qualitative,Quantitative, a nd Mixed Second Edition. 2012.

[43] J. R. Fraenkel, N. E. Wallen, and H. H. Hyun, How to Design and Evaluate Research in Education. New York.: McGraw-Hill Companies, 2012.

[44] G. A. D. Sugiharni and N. W. Setiasih, "Validitas dan Reliabilitas Instrumen Evaluasi Blended Learning Matakuliah Matematika Diskrit di STIKOM Bali Berbasis Model Alkin,” Indomath Indones. Math. Edcuation, vol. 1, no. 2, pp. 93-108, 2018.

[45] M. D. C. Tongco, "Purposive Sampling as a Tool for Informan Selection,” Ethnobot. Res. Appl., vol. 5, pp. 147158, 2007.

[46] I. Etikan, S. A. Musa, and R. S. Alkassim, "A Comparison Of Convenience Sampling And Purposive Sampling,” $J$. Nurs., vol. 5, no. 1, pp. 1-4, 2014.

[47] M. Jerusalem and R. Schwarzer, "Self-efficacy as a resource factor in stress appraisal processes," in Self-Efficacy: Thought Control Of Action, 2014.

[48] T. Coladarci, C. D. Cobb, E. W. Minium, and R. B. Clarke, Fundamentals Of Statistical Reasoning in Education. New Jersey: John Wiley \& Sons, INc, 2011.

[49] B. M. King and E. M. Minium, "Statistical Reasoning: In
Psychology and Education.” 2003.

[50] A. J. Izenman, Modern Multivariate Statistic Techniques: Regression, Classification, and Manifols Learning. Philadelphia: Springer, 2008.

[51] C. Kestens, "Visual impairments,” Rev. Med. Brux., 2019, doi: 10.5005/jp/books/12882_8.

[52] S. R. Hodge, N. M. Murata, M. E. Block, L. J. Lieberman, and L. J. Lieberman, "Teaching Students with Visual Impairments," in Case Studies in Adapted Physical Education, 2019.

[53] L. J. Lieberman, C. Houston-Wilson, and F. M. Kozub, "Perceived barriers to including students with visual impairments in general physical education,” Adapt. Phys. Act. Q., 2002, doi: 10.1123/apaq.19.3.364.

[54] S. Skaggs and C. Hopper, "Individuals with visual impairments: A review of psychomotor behavior,” Adapted Physical Activity Quarterly. 1996, doi: 10.1123/apaq.13.1.16.

[55] P. Hatlen, "Is social isolation a predictable outcome of inclusive education?,” J. Vis. Impair. Blind., 2004, doi: 10.1177/0145482x0409801102.

[56] D. D. Hatton, "Advancing the education of students with visual impairments through evidence-based practices," in International Review of Research in Developmental Disabilities, 2014.

[57] M. A. Prater, "Inclusion of students with special needs in general education classrooms," in International Encyclopedia of Education, 2010.

[58] S. L. Woodruff and J. F. Cashman, "Task, Domain, and General Efficacy: A Reexamination of the Self-Efficacy Scale,” Psychol. Rep., 1993, doi: 10.2466/pr0.1993.72.2.42 3.

[59] T. J. Maurer and H. R. Pierce, “A comparison of likert scale and traditional measures of self-efficacy,” J. Appl. Psychol., 1998, doi: 10.1037/0021-9010.83.2.324.

[60] D. Hernawati, M. Amin, M. Irawati, S. Indriwati, and M. Aziz, "Integration of project activity to enhance the scientific process skill and self-efficacy in Zoology of Vertebrate teaching and learning," Eurasia J. Math. Sci. Technol. Educ., 2018, doi: 10.29333/ejmste/89940.

[61] F. Teng, "The effects of task-induced involvement load on word learning and confidence judgments mediated by knowledge and regulation of cognition," Kuram ve Uygulamada Egit. Bilim., 2017, doi: 10.12738/estp.2017.3. 0167.

[62] N. D. L. Kurniawati and A. Mahmudi, "Analysis of mathematical literacy skills and mathematics self-efficacy of junior high school students," in Journal of Physics: Conference Series, 2019, doi: 10.1088/1742-6596/1320/1/0 12053.

[63] H. D. Brown, Language Assesment Principles and Classroom Practice. 2003.

[64] S. Fairbairn and H. D. Brown, "Language Assessment: Principles and Classroom Practices. H. Douglas Brown,” TESOL Q., 2005, doi: 10.2307/3588320. 
[65] A. Matsuda, Principles and practices of teaching English as an international language. 2012.

[66] N. Javanbakht and M. Hadian, "The Effects of Test Anxiety on Learners' Reading Test Performance,” Procedia - Soc. Behav. Sci., 2014, doi: 10.1016/j.sbspro.2014.03.481.

[67] Z. Ghabanchi and R. Rastegar, "The correlation of IQ and emotional intelligence with reading comprehension,” Read. Matrix An Int. Online J., 2014.

[68] L. Fonteyne, W. Duyck, and F. De Fruyt, "Program-specific prediction of academic achievement on the basis of cognitive and non-cognitive factors," Learn. Individ. Differ., 2017, doi: 10.1016/j.lindif.2017.05.003.

[69] W. S. Riani and Y. A. Rozali, "Hubungan antara self efficacy dan kecemasan saat presentasi pada mahasiswa univeristas esa unggul,” J. Psikol., 2014.

[70] A. I. D. Anwar, "Hubungan antara self-efficacy dengan kecemasan berbicara di depan umum pada mahasiswa fakultas psikologi universitas sumatera utara,” Psikovidya Vol. 18 Nomor 1 April 2014, 2009.

[71] L. F. Blumenthal, "Self-efficacy in low-level English language learners,” Portland State University, 2014.

[72] R. C. Gardner and P. D. Macintyre, “A Student's Contributions to Second-Language Learning. Part II:
Affective Variables,” Lang. Teach., vol. 26, no. 1, pp. 1-11, 1993, doi: 10.1017/S0261444800000045.

[73] R. C. Gardner and P. D. MacIntyre, “A student's contributions to second language learning. Part I: Cognitive variables,” Lang. Teach., vol. 25, no. 04, pp. 211-220, 1992, doi: 10.1017/S026144480000700X.

[74] J. A. Turi, S. Sorooshian, and Y. Javed, "Impact of the cognitive learning factors on sustainable organizational development,” Heliyon, 2019, doi:10.1016/j.heliyon.2019.e 02398.

[75] S. M. Gamlem and K. Smith, "Student perceptions of classroom feedback,” Assess. Educ. Princ. Policy Pract., 2013, doi: 10.1080/0969594X.2012.749212.

[76] K. D. Vattøy and K. Smith, "Students' perceptions of teachers' feedback practice in teaching English as a foreign language," Teach. Teach. Educ., 2019, doi: 10.1016/j.tate.2019.06.024.

[77] L. R. Harris, G. T. L. Brown, and J. Dargusch, "Not playing the game: student assessment resistance as a form of agency," Aust. Educ. Res., 2018, doi: 10.1007/s13384-018-0264-0.

[78] D. El-Hmoudova, “Assessment of Individual Learning Style Preferences with Respect to the Key Language Competences,” Procedia - Soc. Behav. Sci., 2015, doi: 10.1016/j.sbspro.2015.01.086. 